\title{
PENGARUH MODEL PICTURE AND PICTURE TERHADAP KEMAMPUAN MENULIS TEKS BERITA
}

\author{
Isti Sitihindun ${ }^{1}$, Willyana $^{2}$ \\ 1,2STKIP Subang \\ 1isti.ndun@gmail.com, ${ }^{2}$ willyanaramlan25@gmail.com
}

\begin{abstract}
There were several reasons for conducting this study, students' seriousness in attending writing news text were still low and not excited. Therefore, the teacher must choose and apply an effective teaching learning model to improve students' abilities in writing news text. This study aims to improve students' abilities in writing news text through picture and picture model and investigated students' responses through teaching writing news text by using picture and picture. The experiment is the research method of this study. The control and experiment class were given pretest and post-test to know the students' abilities before and after treatment. The questionnaire also used to gain the data about students' responses through teaching writing news text by using picture and picture. The research finding shows that the picture and picture model is effective to improve students' ability in writing news text. The indicators of the success are that: (1) the mean of pre-test result in the experiment class was 48.71, meanwhile the mean of post-test result was 69.03; (2) the students' responses through questionnaires found that the application picture and picture model was very positive.
\end{abstract}

Key words : Picture and Picture, News Text, Writing

\begin{abstract}
ABSTRAK
Terdapat beberapa alasan yang melatarbelakangi penelitian ini, keseriusan siswa dalam mengikuti pembelajaran menulis teks ceramah masih rendah, siswa tidak antusias pada saat pembelajaran menulis teks ceramah, kurangnya kebiasaan menulis. Oleh karena itu, Guru dapat memilih dan menerapkan suatu model pembelajaran yang lebih efektif untuk meningkatkan keterampilan siswa dalam menulis teks berita. Penelitian ini bertujuan meningkatkan keterampilan menulis teks berita melalui model pembelajaran picture and picture dan untuk mengetahui respon siswa terhadap pembelajaran menulis teks berita dengan menggunakan model pembelajaran picture and picture. Metode penelitian ini adalah eksperiment, yang menggunakan kelas kontrol dan kelas eksperiment, kedua kelas diberikan pretes untuk mengetahui keadaan awal dari masing-masing kelas, setelah itu diberikan postes untuk mengetahui keadaan akhir masing-masing kelas. Dan angket untuk mengetahui respons siswa terhadap pembelajaran menulis teks ceramah dengan menggunakan model pembelajaran picture and picture. Penelitian ini menunjukkan bahwa nilai preteset dengan nilai rata-rata 48,71 , sedangkan hasil hasil posttest dengan nilai rata-rata 69,03. Dengan demikian terdapat perbedaan hasil belajar yang signifikan antara siswa kelas kontrol dan kelas eksperiment. Respon siswa sangat posiitif terhadap penggunaan model pembelajaran picture and picture.
\end{abstract}

Kata Kunci: Picture and Picture, Menulis, Teks Berita 
Didaktik : Jurnal IImiah PGSD STKIP Subang, ISSN Cetak : 2477-5673 ISSN Online : 2614-722X Volume VI Nomor 01, Juni 2020

\section{A. Pendahuluan}

Banyak ragam bahasa tulis sebagai media penyampaian pesan.

Salah satu ragam bahasa tulis adalah menulis teks berita. Berita adalah laporan mengenai peristiwa atau kejadian yang aktual, terjadi di luar dugaan dan menarik perhatian banyak orang. Tarigan (2013:3) menulis merupakan suatu keterampilan berbahasa yang yang dipergunakan untuk berkomunikasi secara tidak langsung, tidak secara tatap muka dengan orang lain. Dalam kegiatan menulis, penulis harus tampil memanfaatkan georafis, struktur bahasa, dan kosa kata. Semi (1995:11) mengungkapkan bahwa berita adalah cerita atau laporan mengenai kejadian atau peristiwa yang faktual baru dan luar biasa sifatnya. Djuraid

(2012:9)

mengemukakan bahwa berita adalah laporan atau pemberitahuan mengenai terjadinya sebuah peristiwa atau keadaan yang bersifat umum dan baru saja terjadi yang disampaikan oleh wartawan di media massa.

Kegiatan belajar mengajar terutama mata pelajaran bahasa Indonesia khususnya pembelajaran menulis teks berita masih terdapat beberapa kekurangan atau kendala.
Mulai dari penggunaan model atau media yang kurang efektif sehingga dalam kegiatan belajar mengajar menjadi sia-sia atau tidak optimal dan tidak akan ada perkembangan untuk kemampuan menulis teks berita. Begitupun dengan siswa yang masih pasif dan menjadikan pembelajaran selalu berpusat pada guru.

Pembelajaran di sekolah terkadang membosankan yang menjadikan siswa tidak berkembang dan menjadi pasif. Mengidentifikasi suatu peristiwa di kelas juga merupakan faktor utama dalam memilih suatu strategi pembelajaran. Salah satu model pembelajaran yang dapat dijadikan sebagai alternatif solusi dalam mengatasi permasalahan pendidikan bahasa Indonesia khususnya dalam kemampuan menulis teks berita adalah pembelajaran bahasa Indonesia dengan model picture and picture.

Menurut Suprijono dalam Huda (2018:236), picture and picture merupakan straregi pembelajaran yang menggunakan gambar sebagai media pembelajaran.

$$
\text { Ngalimun } \quad \text { (2014: }
$$
menegaskan bahwa picture and picture adalah sajian informasi 
Didaktik : Jurnal IImiah PGSD STKIP Subang, ISSN Cetak : 2477-5673 ISSN Online : 2614-722X Volume VI Nomor 01, Juni 2020

kompetensi, sajian materi, perlihatkan gambar kegiatan berkaitan dengan materi, siswa mengurutkan gambar sehingga sistematik, guru mengkonfirmasi urutan gambar tersebut, guru menanamkan konsep sesuai materi bahan ajar, penyimpulan, evaluasi, dan refleksi.

Dalam penelitian ini mendeskripsikan gambaran yang nyata pengaruh pembelajaran menulis teks berita dengan model picture and picture terhadap peningkatkan kemampuan menulis siswa.

\section{B. Metode Penelitian}

Penelitian ini menggunakan jenis penelitian kuantitatif. Penelitiannya diarahkan untuk mencari data kuantitatif yang kemudian diolah dengan menggunakan analisis statistik. Dalam penelitian ini, peneliti menggunakan metode eksperimen. Metode ini menurut peneliti akan mempermudah dalm melaksanakan penelitian, karena dalam metode ini terdapat pretest dan postest. Metode penelitian eksperimen dapat diartikan sebagai metode penelitian yang digunakan untuk mencari pengaruh perlakuan tertentu terhadap yang lain dalam kondisi yang terkendalikan (Sugiyono, 2012:72). Jadi penelitian ini menggunakan desain preexperimental design dengan bentuk one-group pretest-posttest design.

Jumlah populasi dalam penelitian ini adalah 62 siswa. Sampel yang digunakan dalam penelitian ini adalah random sampling, yaitu kelas VIII A yang berjumlah 31 siswa sebagai kelas eksperimen dengan data dianalisis menggunakan rumus mencari skor rata-rata, normalitas, homogenitas, uji hipotesis, dan perhitungan n-gain.

Lokasi penelitian ini dilakukan di SMP Negeri Satu Atap Karya Utama. Lokasi sekolah berada di Jalan Cihuni Rt 13/04, Desa Cimayasari, Kecamatan Cipeundeuy, Kabupaten Subang, Jawa Barat 41212. Untuk memperoleh data yang diharapkan, peneliti menggunakan beberapa instrumen yang meliputi wawancara, tes pretest-postest, rubrik penilaian menulis teks berita, dan dokumentasi.

Adapun prosedur untuk pengolahan datanya adalah sebagai berikut:

1. Uji nilai rata-rata

Langkah-langkah menganalisis nilai rata-rata data adalah sebagai berikut:

a) Menganalisis hasil tulisan siswa. 
Didaktik : Jurnal IImiah PGSD STKIP Subang, ISSN Cetak : 2477-5673 ISSN Online : 2614-722X Volume VI Nomor 01, Juni 2020

b) Mennentukan skor tes awal dan skor tes akhir.

c) Mendeskripsikan hasil tes awal dan tes akhir. Untuk analisis nilai rata-rata menggunakan bantuan softwere SPSS 23 For Window.

2. Uji Normalitas

Normalitas data kerap kali disertakan dalam suatu analisis statistika inferensial untuk satu sehingga lebih dari satu kelompok sampel. Uji normalitas merupakan sebuah uji yang bertujuan untuk menilai sebuah data, apakah data tersebut berdistribusi normal, normal atau tidaknya sebuah data distribusi dapat dilakukan dengan menggunakan persamaan chi-kuadrat (Subana dan Sudrajat, 2009:149). $\mathrm{H}_{0}$ : Sampel berasal dari populasi yang berdistribusi normal. $\mathrm{H}_{\mathrm{a}}$ : Sampel berasal dari populasi yang tidak berdistribusi normal. Dengan taraf signifikansi (a) sebesar 0,5 dapat disimpulkan bahwa nilai signifikansi > 0,05 maka $\mathrm{H}_{0}$ diterima. Dan $\mathrm{H}_{0}$ ditolak jika nilai signifikansi $<0,05$. Untuk uji normalitas menggunakan bantuan softwere SPSS 23 For Window.

3. Uji Homogenitas

Uji homogenitas ini dilakukan untuk mengetahui apakah variansvarians dari populasi tersebut homogen atau tidak. Adapun rumus untuk mengolah datanya adalah sebagai berikut.

$$
\mathrm{F}=\frac{\text { vaians terbesar }}{\text { varians terkecil }}
$$

Untuk menentukan suatu data dikatakan homogen atau tidak, dapat menggunakan kriteria sebagai berikut (Subana dan Sudrajat, 2009:161).

a. Apabila $F_{\text {hitung }}>F_{\text {tabel }}$ maka $\mathrm{H}_{0}$ diterima, artinya data dinyatakan tidak homogen.

b. Apabila $F_{\text {hitung }}<F_{\text {tabel }}$ maka $\mathrm{H}_{0}$ ditolak, artinya data dinyatakan homogen.

Untuk perhitungan uji homogenitas, peneliti menggunakan softwere SPSS 23 For Window.

\section{Uji Hipotesis}

Pengujian hipotesis ini meggunakan statistik paired sampel T test menggunakan SPSS 23, paired sampel t-test digunakan untuk mengetahui apakah terdapat perbedaan rata-rata dua sampel yang sama namun mempunyai dua data. $\bigcup j \mathrm{ji}$ paired sampel t-test merupakan bagian dari statistic parametic, oleh karena itu sebagaimana aturan dalam statistic parametic data haruslah berdistribusi normal. Uji t adalah tes statistik yang dapat dipakai untuk menguji berbedaan atau kesamaan 
Didaktik : Jurnal IImiah PGSD STKIP Subang, ISSN Cetak : 2477-5673 ISSN Online : 2614-722X Volume VI Nomor 01, Juni 2020

dua perlakuan atau dua kelompok yang berbeda dengan prinsip memperbandingkan rata-rata (mean) kedua kelompok perlakuan tersebut (Subana dan Sudrajat, 2009:158). Dasar pengambilan keputusan sebagai berikut.

a. Jika nilai Sig. (2-tailed) $<0,05$, maka terdapat perbedaan yang signifikan antara hasil belajar pada data pretest dan posttest.

b. Jika nilai Sig. (2-tailed) > 0,05, maka tidak terdapat peredaan yang signifikan antara hasil belajar pada data pretest dan posttest.

5. Perhitungan N-Gain

Untuk menngetahui peningkatan kemampuan menulis teks berita peserta didik, dianalisis menggunakan software SPSS 23 for windows. Dengan kriteria indeks gain menurut Hake (Yunus, 2013:41) sebagaimana terdapat dalam tabel berikut.

Tabel. 1

Kriteria Indeks Gain

(Sumber:Yunas, 2013:41)

\section{Hasil dan Pembahasan}

Berdasarkan statistik deskriptif data pretest dapat dilihat nilai rata-rata adalah 48,71 dengan skor minimum 35,00 dan skor maksimum 70,00.
Sementara standar devisi untuk kelas eksperimen adalah 8,753. Data tersebut menunjukan kemampuan menulis berita masih rendah. Selanjutnya, berdasarkan statistik deskriptif data posttest dapat dilihat bahwa nilai rata-rata adalah 69,03 dengan skor minimum 50,00 dan skor maksimum 90,00. Sementara standar deviasi kelas eksperimen adalah 11,791 Data tersebut menunjukan bahwa peningkatan skor terjadi setelah data sebelumnya menggunakan model pembelajaran picture and picture.

Uji normalitas, dapat dilihat dari hasil pengujian normalitas pemahaman pembelajaran menulis teks berita menggunakan model picture and picture dengan melihat data yang diperoleh dari penghitungan uji normalitas di atas, dapat dilihat Kolmogorov-Smirnov bahwa nilai sinifikansi pretest 0,192 dan posttest 0,200 (distribusi normal).

Uji homogenitas dilakukan dengan Analysis of variance (ANOVA), dalam perhitungan pengujiannya dilakukan dengan menggunakan SPSS. Dari output di atas, lihat pada kolom test of homogeneity of variances dapat diketahui bahwa nilai signifikansi 
pretest dan posttest yaitu 0,079 (varian sama.).

Uji paired sampel t-test diketahui bahwa nilai Sig. (2-tailed) sebesar $0,000<0,05$. Dengan demikian, pengaruh menggunakan model picture and picture terhadap kemampuan menulis teks berita terdapat perbedaan nyata antara hasil

\begin{tabular}{|c|l|}
\hline Indeks Gain & Keterangan \\
\hline$g \geq 0,70$ & Tinggi \\
\hline $0,30<g \leq 0,70$ & Sedang \\
\hline$g \leq 0,30$ & Rendah \\
\hline \multicolumn{2}{|c|}{ menggunakan model }
\end{tabular}

pembelajaran picture and picture pada data pretest dan posttest.

Uji N-Gain adalah uji untuk melihat efektivitas model yang digunakan atau diterapkan. Dengan melihat indeks gain $0,30<g \leq 0,70$, yaitu dengan kriteria sedang. Dapat diketahui dari tabel di atas nilai ratarata $\mathrm{N}$-Gain adalah sebesar 0,41 termasuk ke dalam kriteria sedang. Jadi, dapat disimpulkan efektivitas model pembelajaran picture and picture dalam menulis teks berita adalah kategori sedang.

\section{Kesimpulan}

Berdasarkan hasil penelitian dan pembahasan di atas maka dapat disimpulkan hasil penelitian ini sebagai berikut.

1. kemampuan siswa dalam menulis teks berita sebelum menggunakan model pembelajaran picture and picture termasuk dalam kategori kurang baik dan tidakn berhasil. Hal ini terbukti dengan nilai rata-rata siswa yakni 48,71.

2. Kemampuan siswa dalam menulis teks berita sesudah menggunakan model pembelajaran picture and picture termasuk kategori baik dan berhasil. Hal ini terbukti dari nilai rata-rata siswa yakni 69,03.

3. Berdasarkan perhitungan statistik data nilai hasil tes pretest yang tidak menggunakan model pembelajaran picture and picture diperoleh nilai rata-rata 48,71 , sedangkan hasil posttest dengan menggunakan model pembelajaran picture and picture diperoleh nilai rata-rata 69,03 . Nilai angka pretest dan posttest terdapat perbedaan dan peningkatan yakni 20,32. Dengan demikian dapat disimpulkan bahwa terdapat yang nyata antara hasil belajar menggunakan model pembelajaran picture and picture pada data pretest dan posttest. 


\section{DAFTAR PUSTAKA}

Djuraid (2009). Panduan Menulis Berita. Malang: UPT Penerbitan Universitas Muhammadiyah Malang.

Huda,Miftahul (2018). Model-model Pengajaran dan Pembelajaran. Pustaka Pelajar Celeban Timur UH III/548 Yogyakarta.

Ngalimun (2014). Strategi dan Model Pembelajaran. Jakarta: Aswada Paressindo.

Semi, Atar (1995). Teknik Penulisan Berita, Feature dan Artikel. Bandung: Angkasa Raya.

Subana dan Sudarajat (2009). Dasardasar Penelitian. Bandung: Pustaka Setia.

Sugiyono (2012). Metode Penelitian (Pendekatan kuantitatif, kualitatif, $R \& D)$. Bandung: Alfabeta.

Tarigan, Henry Guntur (2013). Menulis Sebagai Suatu Keterampilan Berbahasa. Bandung: Angkasa.

Yunas, Febrisa (2013). Media Pembelajaran: Sebuah Pendekatan Baru. Jakarta: Referensi. 